\title{
WOBEC NIE-MIEJSCA. MYŚLENIE PRZESTRZENIĄ W TWÓRCZOŚCI ÁDÁMA BODORA ${ }^{1}$
}

\author{
KINGA PIOTROWIAK-JUNKIERT ${ }^{2}$ \\ (Poznań)
}

Słowa kluczowe: Ádám Bodor, przestrzeń, pogranicza, prowincja, geopoetyka, tożsamość

Keywords: Ádám Bodor, space, borderlands, province, geopoetics, identity

\begin{abstract}
Abstrakt: Kinga Piotrowiak-Junkiert, WOBEC NIE-MIEJSCA. MYŚLENIE PRZESTRZENIĄ W TWÓRCZOŚCI ÁDÁMA BODORA. „PORÓWNANIA” 11, 2012, Vol. XI, ss. 101-110, ISSN 1733-165X. Artykuł prezentuje analizę koncepcji przestrzeni w twórczości Ádama Bodora (Okręg Sinistra, Wizyta arcybiskupa). Konstrukcja powieści węgierskiego pisarza pozwala stwierdzić, że mamy w tych powieściach do czynienia ze szczególną formą fabularnej przestrzeni. Bodor opisuje miejsca, które nie istnieją w rzeczywistości pozatekstowej, nadając im jednak nazwy, które stają się rodzajem wskazówki, podpowiedzi. Czytelnik z łatwością może dekodować nazwy przygranicznych terenów opisywanych $w$ tej twórczości. Bodor opiera swój koncept także na fiozofii wpisanej w zaburzenie cyklicznych procesów przyrody, metaforach totalitarnego świata, byciu wiecznym tułaczem.
\end{abstract}

Abstract: Kinga Piotrowiak-Junkiert, TOWARDS NON-PLACE. THINKING IN TERMS OF SPACE IN ÁDÁM BODOR'S WORLD. „PORÓWNANIA” 11, 2012, Vol. XI, pp. 101-110, ISSN 1733-165X The article presents an analysis of the spatial conception in the works of Ádam Bodor (The Sinistra Zone, The Archbishop visit). The construction of the novels written by the Hungarian writer depicts that in this novel there appears a particular story space. Bodor describes places, which didn't exist in external reality. He also gives them names which constitute a type of hint. The readership can easily decode the names of the borderlands. The writer constructs these ideas based on his own philosophy which is connected with perturbations of the cyclical processes of nature, metaphors of the totalitarian world but also being the eternal Wanderer.

\footnotetext{
1 Praca naukowa finansowana w ramach programu Ministra Nauki i Szkolnictwa Wyższego pod nazwą "Narodowy Program Rozwoju Humanistyki” w latach 2012-2014. (H)

2 Correspondence Address: kinga.piotrowiak@gmail.com
} 
Koncepty „wyimaginowanych/wyobraźniowych światów” przenikające i modelujące uniwersum powieściowej twórczości Ádáma Bodora ${ }^{3}$, mimo dzielących je istotnych różnic, wynikających z odmiennych konstrukcji fabularnych rzeczywistości, łączy szczególna relacja, rodzaj myślowego pokrewieństwa. Powinowactwo to ma związek $\mathrm{z}$ unikatowym sposobem traktowania przestrzeni, która zamiast być - zgodnie z ustaleniami klasycznej teorii dzieła literackiego - jednym z komponentów współbudujących świat przedstawiony tekstu, staje się główną jego osią, punktem centralnym, nadrzędną „wartościotwórczą” kategorią ${ }^{4}$. W prozie Ádáma Bodora wyjątkowa rola przestrzeni ma związek z jeszcze jedną odautorską inicjatywą: miejsca, w których ulokowane są fabuły opowieści, w rzeczywistości nie istnieją. Słowotwórcza budowa nazw własnych miejscowości, osad, przyczółków, strażnic i łańcuchów górskich sugeruje jednak w dyskretny sposób, o jakiej przestrzeni jest mowa, by "geoprzestrzenne"/,geopoetyczne" podróże w głąb tekstu były ukierunkowane i - wskutek tego - nacechowane znaczeniami, płynącymi z kulturowej pamięci (o) przestrzeni, w której rozgrywają się powieściowe fabuły.

\section{JAKA WŁAŚCIWIE JEST PRZEŁĘCZ?}

Györgyi Fodor, analizująca w eseju Az érsek szava (Słowo arcybiskupa) budowę magicznego świata Bodora i filmową adaptację jego powieści ${ }^{5}$, zwróciła uwagę na

${ }^{3} \mathrm{~W}$ tekście posługuję się skrótami literowymi, które odsyłają do następujących wydań książek: [OS]: Á. Bodor, Okręg Sinistra. Przeł. M. Komorowska. Wołowiec 2001; [ZP]: Á. Bodor, Zapach więzienia. Odpowiedzi na pytania Zsófi Balla (na podstawie wywiadu radiowego). Przeł. M. Komorowska-Fotek. Wołowiec 2004; [WA]: Á. Bodor, Wizyta arcybiskupa. Przeł. M. Komorowska-Fotek. Wołowiec 2002; [ZPDUS]: Á. Bodor, Z powrotem do uszatej sowy. Przeł. M. Komorowska-Fotek, T. Olszański, E. Sobolewska. Wołowiec 2007.

${ }^{4}$ Analizę koncepcji „przestrzeni” oraz jej znaczenia dla badań literackich i kulturowych prezentują m.in. prace: Yi-Fu Tuan, Przestrzeń i miejsce. Przeł. A. Morawińska. Wstęp K. Wojciechowski. Warszawa 1987; Przestrzeń i literatura. Red. M. Głowiński i A. Okopień-Sławińska. Wrocław 1978; Pamięć, przestrzeń, tożsamość. Red. S. Kapralski. Warszawa 2010; Pogranicza: przestrzeń kulturowa. Olsztyn 2007; Przestrzeń w kulturze i literaturze. Red. i wstęp E. Borkowska. Katowice 2006; W. Toporow, Przestrzeń i rzecz. Przeł. B. Żyłko. Kraków 2003; Czas i przestrzeń w prozie XIX i XX wieku. Red. Cz. Niedzielski i J. Speina. Torun 1990.

${ }^{5}$ Mowa o filmie Dolina w reżyserii Zoltána Kamondi z 2007 roku. Ádám Bodor wspomina w wywiadzie udzielonym dla pisma "Székelyföld” o istotnej różnicy pomiędzy pracą reżysera i dostosowywaniem tekstu do warunków filmowego odbioru a własnym konceptem powieści, która jest w zdecydowanej mierze indywidualnym, prywatnym obrazem. „Praca reżysera jest w większej mierze ukierunkowana, bezpośrednia, niż moja. On na przykład postrzega dyktaturę poprzez jej jawną przemoc, ja z kolei w bolesnym ucisku żeber". Zs. Andrea, Ne kíméljük az olvasót, ha már... (Beszélgetés Bodor Ádám íróval). „Székelyföld” 2006, nr 3, s. 86-109. Twórczość Bodora była przenoszona na ekran filmowy wielokrotnie. W 1972 powstał film Forró vizet a kopaszra (Wrzatkiem w tysego) w reżyserii Pét- 
podstawowy warunek odbioru dzieł(a) autora Wizyty arcybiskupa, który opiera się na traktowaniu "czytelnika-turysty” [olvasó-turista] jako kogoś, kto umiejętnie odszyfrowuje zakodowany świat symboli i metafor oplatający tekstowe uniwersum autora:

Gdybyśmy ofiarowali Ádámowi Bodorowi dowolny obraz świata, musiałby on niezwłocznie poplątać linie jego granic i przemianować nazwy górskich wzniesień tak, by były one wszędzie i dla każdego zrozumiałe, a później musiałby obsypać go pyłem magicznego języka, doskonale zrozumiałym dla każdego czytelnika-turysty, dla którego nie ma znaczenia najmniejsza nawet rzeczywista informacja ${ }^{6}$.

Uwaga węgierskiej krytyczki zmusza do postawienia pytania, wokół którego koncentruje się poetycki świat prozy Bodora: w jaki sposób twórca powinien kreować przestrzeń, by przekraczała ona dotychczasową rolę fabularnej scenografii, na rzecz pełnowartościowego, kulturotwórczego tworzywa, porządkującego myślenie o własnej tradycji, historii a nawet narodowej/europejskiej wyobraźni?

Ádám Bodor wybiera w swojej twórczości pograniczny teren Gór Gyulai [Gyulai havasok]7, który ukrywa pod wyimaginowaną nazwą 'okręg Sinistra' i 'Bogdańska Dolina' (Wizyta arcybiskupa). "Jedyne miejsce, które faktycznie można odnaleźć na mapach, to górski szczyt Pop Ivan - twierdzi Bodor w wywiadzie-rzece Zapach więzienia (2001) - Z grubsza właśnie w jego okolicy umieszczam akcję moich historii" [ZW,170] $]^{8}$. Zapamiętana z dzieciństwa „baśniowa kraina” [ZW,14] Siedmiogrodu, znana $\mathrm{z}$ wielokulturowego bogactwa i mozaiki języków (węgierskiego, rumuńskiego, ukraińskiego, szwabskiego, serbskiego) prezentowana jest $\mathrm{w}$ powieściach jako przestrzeń hermetyczna, niedostępna dla przypadkowych wędrówców („internowanych" [OS,109]) a wszystkie znane w naturze cykle przyrody i uniwersalne (humanistyczne) porządki wartości są radykalnie zachwiane, a nawet nieodwracalnie zdezawuowane.

Bohaterzy Bodora bez trudu spostrzegają zmiany pór roku, ponieważ ich trwanie limitowane jest obecnością ${ }^{9}$ konkretnych gatunków ptaków (jemiołuszki,

era Bacsó (scenariusz P. Bacsó, P. Zimre), w 1973 Plusz-mínusz egy nap (Plus minus jeden dzień) w reżyserii Zoltána Fábri (scenariusz Z. Fábri, P. Zimre) oraz A részleg (Wydziat) w 1994, w reżyserii Pétera Gothára (scenariusz P. Gothár i Á. Bodor).

6 Gy. Fodor, Az érsek szava. Bodor Ádám és Érsek látogatása cimü könyvéról és Kamondi Zoltán filmadoptációjáról - tanulmány, w: http://www.lato.ro/article.php/Az-\%C3\%A9rsek-szava/1499/ (data dostępu: 10.06.2012 r.).

7 Góry Gyulai [Góry Andrassy'ego, pol. Góry Gilău] - masyw górski w Górach Zachodniorumuńskich znajdujący się na terenie Siedmiogrodu.

8 Bodor wskazuje jeszcze jedną nazwę geograficzną - szczyt Dobrin. W Okręgu Sinistra nazwę tę nosi kompleks leśnych domostw znajdujący się w rezerwacie, zamieszkiwany przez bohaterów powieści i nazwany żartobliwie „Dobrin City” [OS,17].

${ }^{9} \mathrm{Z}$ wyłączeniem powieściowego świata ostatniej książki Bodora Verhovina madarai (Ptaki Verhoviny, 2011), dla której znamienna jest właśnie „nieobecność ptaków”. 
dzikie gęsi) lub owocowaniem roślin i ogranicza się jedynie do kilkunastu dni a czasami nawet kilku godzin: „jeszcze tydzień, dwa tygodnie temu płonęła tu wszędzie jarzębina, teraz wokoło czerniły się tylko puste, łyse gałęzie - jak zwykle przed nadejściem mroźnych północnych wiatrów zawitały tu jemiołuszki" [OS,45]. Pewne stany przyrody nie ulegają cyklicznemu przemianowaniu, Andrej Bodor bohater Okregu Sinistra noszący nazwisko pisarza - ze zdumieniem zauważa, że pozostawione przez niego przed laty ślady nart są widoczne gołym okiem, mimo że zgodnie z procesami regulującymi cyrkulację materii, dawno powinny ulec stopieniu:

Na rozgrzanej wiosennym słońcem łące zobaczyłem prowadzące hen, w głąb lasu ślady moich własnych nart. Przetrwały tu od ostatniej zimy, którą wiele lat temu spędziłem na przełęczy (...). Takie podwójne ślady, jedwabne, posrebrzane światłem wstęgi, zazwyczaj topnieją dopiero na początku lata. Są jednak i takie, które nie topnieją nigdy $[\mathrm{OS}, 18]$.

Rewersem wszystkich zaburzeń naturalnego cyklu przemian dynamizującego świat przyrody jest istotne rozchwianie stanów określających egzystencję uczestników tej przestrzeni. Istnienie bohaterów przekracza a nawet przeczy własnym, przyrodzonym ograniczeniom - umiera się z powodu deszczu, a zmarli są wskrzeszani wskutek prostych czynności restytucyjnych. O Coce Mavrodin-Mahmudia, następczyni pułkownika Borcana, pisze Bodor:

Zdrzemnęła się w lesie na siedząco i zaskoczył ją marznący deszcz. Tak długo siedziała nieruchomo jak śpiąca ćma, aż pokryły ją lodowe krople, pod którymi zamarzła na kość. Jakiś czas później wiatr przewrócił bryłę lodu. Ta rozpadła się na drobne kawałki, po czym zwyczajnie stopniała [OS,51-52].

Zmiany dokonujące się w obrębie habitusu bohaterów dotykają także podstawowego narzędzia modelującego ich wzajemne relacje - werbalnej i niewerbalnej komunikacji. Coca Mavrodin informuje mieszkańców Dobrina o swoich decyzjach, zlecając umieszczanie wstążeczek z rozkazami na drzewach i krzewach, ale ze zrozumiałych względów rzadko docierają one do adresatów. Z kolei Andrej Bodor poszukujący zaginionego syna, Béli Bundasiana, dowiaduje się o miejscu pobytu syna dzięki mikroskopijnemu napisowi: „Wiadomość została wygrawerowana igłą na dwudziestaku, którego [...] jakiś urzędnik państwowy o szlachetnych porywach - wrzucił mi do skrzynki na listy" [OS,33].

Wyraźne translokacje dokonujące się w obrębie ludzkich zachowań, reakcji, postaw moralnych i rytualnych polegają zatem na wyłączeniu/lub zachwianiu istnienia bohaterów z szeregu procesów kształtujących oraz regulujących ich egzystencję i mają nierozerwalny związek z obowiązkiem obecności w obrębie określonej przestrzeni, która $\mathrm{w}$ widoczny, choć właściwie niemożliwy do wyjaśnienia sposób, modeluje wszelkie przejawy ich życia. Według Kornélii Faragó (Szituatív 
térszerkezetek. A dinamikus-poláris formáltság - Sytuacyjne konstrukcje przestrzeni. Formowanie o charakterze skrajnie dynamicznym), analizującej zjawisko dynamicznego i biegunowego formowania stosunków przestrzennych w Okregu Sinistry, przestrzeń, w obrębie której dokonuje się istnienie bohaterów powieści Bodora ulega pewnemu specyficznemu rozszerzeniu o elementy budujące wrażenie powtarzalności: „wyruszenie w drogę, stan 'bycia w drodze', dotarcie na miejsce, oczekiwanie, obserwacja terenu, spotkanie lub na przykład sytuacja śmierci". Wszystkie czynności, także procesy słownej komunikacji ujawniają się, zdaniem Faragó, poprzez kontekstualne, wyrywkowe przywoływanie przestrzeni, która nigdy nie objawia się cała, w pełnej postaci, ale jako fragment, dopowiedziany i sugerowany przez kontekst wypowiedzi, szczegół, czy detal. Jest to zatem przestrzeń towarzysząca, obecna jedynie sytuacyjnie ${ }^{10}$.

Pamiętać jednak trzeba, że mimo „scenograficznego" sposobu funkcjonowania przestrzeni $\mathrm{w}$ fabułach Bodora, nie jest ona pozbawiona osobnego, autorskiego namysłu, który pozwala mówić o powieściowym fenomenie przyrody. Zdaniem Enikő Boros (A Sinistra körzet motívumhálója - Sieć motywów w Okręgu Sinistry) określić go można jako archetypiczny, z uwagi na szczególny rodzaj „stopienia”, wzajemnego przenikania się: „perspektywa, z której Bodor każe obserwować naturę istnienia zawiera $\mathrm{w}$ sobie rodzaj prastarego, wspólnotowego wpływu: magia natury jest rodzajem uważnego zatopienia w niej"11 - twierdzi badaczka. Stworzenie zagadkowej krainy, która nie ma swojego odpowiednika w pozatekstowej rzeczywistości jest według węgierskiej badaczki przejawem pierwotnego pragnienia powrotu do wspólnotowej harmonii, do przestrzennego matecznika, w którym porządek przyrody i zamieszkującego ją człowieka mogą stanowić szczególny rodzaj porozumienia, jedności. Warto przywołać postulat Margit Ács, która twierdziła:

Istnienie w naturze jest takim archaicznym wspólnotowym rodzajem współżycia z naturą, które objawia się przez istnieniowe odczucie wypływające z nieświadomości, tam gdzie jeszcze nie dotarł archetypiczny, demonicznie pociągający obraz „bezkresnego lasu"12.

Archetyp ten potraktować można jako metaforę uniwersum, symbol pierwotnej siły porządkującej wszechświat. Zdaniem Boros, rozpad niepochowanych ciał umarłych, który można traktować jako zaburzenie porządku obyczajowego, jest też równocześnie obrazem utraconej, ale w pewien sposób upragnionej więzi z żywiołami, do których wraca materia.

${ }^{10}$ K. Faragó, Szituatív térszerkezetek. A dinamikus-poláris formáltság, w: K. Faragó, Térirányok, távolságok. Térdinamizmus a regényben. Újvidék 2001, s. 129.

11 E. Boros, A Sinistra körzet motívumhálója. „Korunk” 2003, nr 5, s. 101.

12 Á. Margit, Az erdő démonikus vonzása. „Holmi” 1992, nr 12, s. 1880. 
W Okręgu Sinistry panują antyczne, kosmologiczne pryncypia: cztery żywioły, ziemia, powietrze, woda i ogień, oraz naturalne substancje ulegające nieustannej przemianie: deszcz, lód, mgła, błoto, śnieg, światło słońca i przepływające chmury. Istota człowieka (humanus) jest tożsama ze swoją sferą bytu. Wraz z mijaniem życia ulega on naturalnej przemianie. Człowiek nie jest osobą, ale pewnym „indywiduum” koegzystującym z naturą, a w jego zwłokach żywioły przyrody dalej istnieją ${ }^{13}$.

Ciało Coci Mavrodin topniejące i przemieszane ze śniegiem staje się cząstką dobrińskich lasów. A pułkownik Borcan, zjedzony przez zwierzęta, powraca do pierwiastokowego porządku natury, buduje wszechświat przez to, że się w nim zatraca.

\section{UNIWERSALIZOWANIE PRZESTRZENI „GUŁAGOWEGO" ŚWIATA}

Myślenie o przestrzeni zmienia się w twórczości Bodora w nową kategorię „myślenie przestrzenią", która jest najważniejszym symbolicznym językiem uniwersalizującym tekstowy przekaz. Utajone motywacje pisarza, przejawiające się w odbieraniu nazwom własnym ich prawdziwego brzmienia, służyć mają przede wszystkim mówieniu o fundamentalnych problemach egzystencji i nawet jeżeli dostrzegamy geograficzne znaczniki, wspomagające identyfikację miejsc opisywanych w książkach pisarza z ich rzeczywistymi odpowiednikami, pierwszym odruchem „czytelnika-turysty” powinna być podróż w głąb istoty człowieka i jego społecznych uwarunkowań oraz porównawcza, krytyczna analiza metaforycznych schematów z powieści z ich realnymi prototypami.

Upoważnia nas do tego także ukryta struktura powieściowych światów, która pod estetyczną warstwą ",języka magicznego" skrywa starannie pomyślane matryce świata sterowanego mechanizmami władzy. W Okregu Sinistra panują przecież wojskowi (najpierw pułkownik Borcan, potem Coca Mavrodin), w Wizycie arcybiskupa - duchowni. Nikt z mieszkańców Dobrina ani Doliny Bogdańskiej nie dysponuje swobodnie swoim życiem. Bohaterzy zdają się posiadać tożsamość „przejściową", "tymczasową", każdy z nich jest tylko "przybyszem”, „wędrowcem”, któremu pozwolono przez pewien czas zamieszkać w „nie-miejscu”. Brak poczucia nieodwołalnej, istnieniowej przynależności do przestrzeni, w której Bodor rozpisuje fabularne losy swoich bohaterów, wiąże się z nieuchronnym wewnętrznym podziałem powieściowego świata na to, co "zewnętrzne" /,wewnętrzne” oraz "swoje" / „obce"14.

${ }^{13}$ E. Boros, op. cit., s. 101.

${ }^{14}$ Kornélia Faragó stosuje rozróżnienie opierające się na zagadnieniach widzialnego, sinistrzańskiego świata i tych terenów, które do niego nie należą, ale pojawiają się opowieściach przybyszów. 
Podział ten nie jest jednak wolny od ciężaru historycznej świadomości, którą posiada nawet najbardziej wyabstrahowany z pozatekstowej rzeczywistości "czytelnik-turysta”. Sytuacja tymczasowej obecności w zamkniętym świecie, który nigdy nie stanie się ojczyzną jest w XX wieku żywą metaforą egzystencji w Europie Środkowowschodniej. $\mathrm{W}$ powieściach Bodora bycie $\mathrm{w}$ przestrzeni, prawo do mieszkania w Dobrinie przejawia się w jednym tylko wizualnym znaku: każdy mieszkaniec nosi na szyi metalową blaszkę z wytłoczonym imieniem i nazwiskiem, które rzadko są prawdziwe. Żaden z bohaterów, który stracił prawo do pobytu w Bogdańskiej Dolinie, czy okręgu Sinistra nie wraca.

Być może stopienie dwóch perspektyw poznawczych: „metaforycznej” (powieściowej) i „realnej” (rzeczywistej) wraz z zachowaniem naturalnego terytorialnego/przestrzennego napięcia, wpisanego w egzystencję ludzi pogranicza pozwala stworzyć taki model przestrzeni, który traktujemy dzisiaj jako wzorcowy, ikoniczny w dyskusji o obliczach Europy Środkowowschodniej. Uważna lektura "magicznego języka” Bodora pozwala zauważyć, że pisarz nie posługuje się nim, by wzmocnić siłę swoich "wyobraźniowych zmyślen" i „autorskich halucynacji” na modłę francuskiej szkoły realizmu magicznego - ale jest to znak aktywnego poszukiwania nowego języka, który udźwignie nie tylko pamięć idyllicznego dzieciństwa, ale przede wszystkim dojrzałą świadomość "gułagopodobnego" $[\mathrm{ZW}, 16]$ świata.

Co się zaś tyczy pogranicza - pisze Bodor -to rzecz jasna, nie przypadkiem jest ono tak często tłem moich opowieści. Jakby nie patrzeć, w przygranicznych prowincjach jest zawsze ciekawiej niż w głębi kraju. To czarowna, tajemna przestrzeń, miejsce ryzykownych przygód, gdzie krajobraz i całe otoczenie naznaczone jest stanem pewnego napięcia. Pogranicze wschodnich krańców Europy było obszarem ogrodzonym szlabanami i drutem kolczastym, krainą najeżoną wieżyczkami strażniczymi i poprzecinaną fosami, gdzie nawet szybujący w powietrzu ptak uważany był za własność państwową $[\mathrm{ZW}, 12]$.

Wszystkie zachwiania norm, od moralnych przez obyczajowe na prawach natury kończąc, służą raczej wyrażeniu niemożliwych do zwerbalizowania absurdów istnienia na terenach ogrodzonych drutem kolczastym, w przestrzeni totalitarnych reżimów, a także sztucznie wytyczanych granic terytorialnych, które nierzadko dzieliły na pół ulice, domy o pogranicznych miasteczkach nie wspominając. Mimo zasadności powyższych rozsądzeń, Bodor daleki jest jednak od radykalnego traktowania własnej twórczości jako materii stworzonej, by skutecznie demaskować prawdę o regułach politycznego bezprawia i przestrzennych gett.

\footnotetext{
Stąd podział na „obecność/bytność” [jelenlét] i „nieobecność” [távollét], pomiędzy którymi rozgrywają się skomplikowane, wzajemnie powiązane życiowe relacje bohaterów. Zdaniem Faragó obie te kategorie wzajemnie się dopełniają, dookreślają i warunkują. Zob. K. Faragó, op. cit., s. 134.
} 
Pisarz koncentruje się raczej wokół umownej kategorii granicy i graniczności - nie tylko tej przestrzennej, geograficznej, ale przede wszystkim istnieniowej, myślowej, moralnej. Dla autora Okręgu Sinistry podstawowym warunkiem i motywem pisania jest bowiem potrzeba swobodnego kreowania rzeczywistości, w której nieuniknione skojarzenia z pozatekstową rzeczywistością powinny towarzyszyć lekturze, ale nie mogą jej zdominować.

\section{POETYKA PROWINCJI I OKRUCH TRIANOŃSKIEGO SZKŁA}

Przedziwne sploty binarnych opozycji, budujące powieściowy świat Bodora nie są pozbawione również pierwiastka narodowego, węgierskiego. Badacze twórczości autora Okręgu Sinistra zwrócili uwagę na te elementy fabularne, które odczytywać można przez pryzmat węgierskiej historii i tradycji. Zdaniem Pétera Sziráka, autora pracy A regionálitás és a posztmodern kánon a XX. századi magyar irodalomban (Regionalność $i$ kanon postmodernistyczny w XX-wiecznej literaturze wegierskiej) "transylwanizm”: „,jest taką kategorią, wynikającą przede wszystkim z sytuacji mniejszości narodowych, która starając się zrozumieć jej duchowo-moralną całość staje się pewną strategią przetrwania"15.

Węgierski badacz definiuje pojęcie "transylwanizmu" jako ideologiczną konstrukcję określającą różne przejawy egzystencji węgierskiej mniejszości, która jako etniczna całość zachowała swoją literacką/kulturową niezależność dzięki umiejętności zgodnego, multikulturowego współistnienia z innymi narodami zamieszkującymi Transylwanię ${ }^{16}$.

Bodor, umieszczający $\mathrm{w}$ przestrzeni swoich powieści przedstawicieli prawie wszystkich narodowości budujących wielkokulturowy tygiel Transylwanii, wiernie oddaje nastrój bogatej w tradycje „,jednej z najbardziej specyficznych prowincji Europy", która - jak twierdzi - mogłaby by być metaforą całej Europy Środkowej. Wielokulturowa mozaika kreowana i ożywiana przez Bodora jest nowoczesną

15 P. Szirák, A regionalitás és a posztmodern kánon a XX. századi magyar irodalomban, w: Nemzetiségi magyar irodalmak az ezredvégen. Red. A. Görömbei. Debrecen 2000, s. 40. W swoim obszernym studium poświęconym zagadnieniu „regionalności”/ „regionalizmu” Szirák zwraca uwagę na podstawowe komponenty budujące przestrzeń i tożsamość regionalną, wskazuje przede wszystkim znaczenie "ruchów ludowych" [népi mozgalom] dla historii ideologii politycznej, kultury i literatury. Autor podkreśla znaczenie d y skursu lud ow ego [népi diskurzus] i (post)romantycznej, modernistycznej tożsamości [(poszt)romantikus nemzeti identitása]. Formowanie się tzw. „myśli siedmiogrodzkiej” [erdélyi gondolat], która stała się „centralnym punktem dyskursu literackiego tworzącego ideologię" tego regionu, prowadziło przez lata przemian literackich i tożsamościowych do narodzin kategorii, nazywanej dzisiaj jako „transylwanizm”.

16 Ibidem, s. 40. 
próbą utrwalania tradycji Siedmiogrodu, pozbawioną jednak elementu mitologizacji, od której pisarz stroni. Nie bez powodu magiczny język powieści towarzyszy opisom brudu, zgnilizny, smrodu, zwłok, odchodów, zaduchu, "gór śmieci" [WA,7], które stają się negatywnym, naturalistycznym tłem wszystkich fabuł Bodora. Symbolizująca potrianońskie rozbicie terytorialne rzeka Medvica - niespodziewanie i podstępnie zmieniając bieg swojego koryta - objawiła terytorialne przemianowanie Bogdańskiej Doliny poprzez zapach:

O tym, że stało się coś strasznego, świadczyć mógł choćby potworny smród setek podmytych wygódek, który uniósł się nad okolicą. W ciągu kilku zaledwie godzin czarnej jak sadza nocy, kiedy wszyscy mieszkańcy - jak to się mówi - spali, Bogdańska Dolina przeszła na drugą stornę rzeki. Do innego kraju [WA,15].

Bodor konsekwentnie odtwarza realia siedmiogrodzkiej rzeczywistości, zanurzając ją jednak $\mathrm{w}$ gorzkiej substancji istnienia pozbawionego perspektyw, w zamkniętych przestrzeniach, które wzmagają poczucie izolacji, braku możliwości rozwoju. Györgyi Pozsvai - autorka monografii poświęconej twórczości Bodora analizuje znaczenie przestrzeni Sinistry, odczytując wszystkie etymologiczne wskazówki, zawarte w nazwie tego powieściowego „nie-miejsca”. Dla badaczki łaciński źródłosłów traktować należy jako symboliczne współbrzmienie myślowych pojęć: „wizji zagrażającego zła”, „mrocznej wróżby”, "przepowiedni nieszczęśliwego końca” oraz „świadomości przemijania”17. Wieloznaczny podział przestrzeni świata przedstawionego na część prawą i lewą (konotowaną przez tytuł powieści) odzwierciedla - zdaniem Pozsvai - problemy na stałe wpisane w terytorialną opozycję pomiędzy wschodem i zachodem - czyli na to, co nieokreślone, odizolowane, zamknięte ${ }^{18}$. Podział ten przywołuje na myśl rzeczywiste granice terytorialne i przestrzenne Europy.

Według Kornélii Faragó, autorki pracy Térirányok, távolságok. Térdinamizmus a regényben (Kierunki przestrzeni, odległości. Przestrzeń i jej dynamika w powieści):

terytorializację, deterytorializację, reterytorializację - dokonującą się na drodze ustaleń, przesunięć i przywróceń - możemy śledzić dzięki badaniu śladów pozostawianych przez te zmiany, a także dzięki historycznemu i kulturalnemu wymiarowi przestrzeni oraz obrazom przestrzeni utrwalonym $\mathrm{w}$ języku ${ }^{19}$.

Obraz przedstawiony przez Bodora nie tylko zachowuje wewnętrzne sprzeczności wpisane w kulturową heterogeniczność Transylwanii (realny odpowiednik

\footnotetext{
17 Gy. Pozsvai, Tér-idő, w: Bodor Ádám. Pozsony 1998, s. 149.

18 Ibidem. Pozsvai przywołuje dwa inne teksty krytyczne poświęcone temu zagadnieniu: G. Angyalosi A kiismerhetetlen remekmü („Hiány” 1992, nr 9, s. 18) i Károlya Alexy, A hely, ahol lak(t)unk („Hitel” 1992, nr 4, s. 82).

${ }^{19}$ K. Faragó, Térirányok, távolságok. Térdinamizmus a regényben. Újvidék 2001, s. 8.
} 
Sinistry), ale także - na drodze konceptualnego projektu przestrzeni nieistniejących miejsc - pozwala traktować tę wyjątkową prowincję, symbolizującą trudne losy polityczne Europy Środkowej, jako matrycę wyrażającą fundamentalne dylematy ludzkiej egzystencji. Bodor zachowuje także najważniejszy element kultury przypisany tej krainie - jej nieujawnioną tajemnicę. Nie wszyscy bohaterzy zmagają się z siłami pierwotnej przyrody, nie wszyscy są „,internowanymi wędrowcami”. Pojawiają się wśród nich również zwykli obserwatorzy, którzy przybyli tutaj, wiedzeni ciekawością tego miejsca. To oni pytają "Jaka jest przełęcz?" 20 . Brak rozstrzygnięcia pozwala traktować Okręg Sinistry jako tekst indukujący i prowokujący dyskuję o roli i znaczeniu przestrzeni zamkniętej, gułagowej. Bodor zadaje pytania: czy można opuścić teren naznaczony i zdominowany przez służby wojskowe?, czy istnieje ktoś, kto jest w tej przestrzeni tubylcem, czy powinniśmy mówić raczej o nieustannym etnicznym, językowym tranzycie wartości i tradycji? Pisarz dochowuje tajemnicy nie-miejsca, nie sugeruje jednoznacznych rozwiązań, ale udowadnia, że kto raz zagości w Sinistrze jest na nią nieodwołalnie skazany.

\footnotetext{
${ }^{20}$ Sformułowanie to nawiązuje do tytułowego opowiadania Bodora Milyen is egy hágó? opublikowanego w tomie opowiadań i szkiców w Budapeszcie, nakładem wydawnictwa Magvető: Á. Bodor, Milyen is a hágó? Válogatott novellák, karcolatok. Budapest 1980.
} 